University of South Florida

DIGITAL COMMONS

Digital Commons @ University of

@ UNIVERSITY OF SOUTH FLORIDA

South Florida

2018

\title{
Stratigraphic Evaluation of Trinity Aquifers in Hays and Western Travis County and Implications for Groundwater Availability
}

\author{
Nicholas Soto-Kerans \\ University of Texas, nicks@mail.usf.edu
}

B. Hunt

B. Smith

Follow this and additional works at: https://digitalcommons.usf.edu/geo_studpub

Part of the Earth Sciences Commons

\section{Scholar Commons Citation}

Soto-Kerans, Nicholas; Hunt, B.; and Smith, B., "Stratigraphic Evaluation of Trinity Aquifers in Hays and Western Travis County and Implications for Groundwater Availability" (2018). School of Geosciences Student Publications. 64.

https://digitalcommons.usf.edu/geo_studpub/64

This Presentation is brought to you for free and open access by the School of Geosciences at Digital Commons @ University of South Florida. It has been accepted for inclusion in School of Geosciences Student Publications by an authorized administrator of Digital Commons @ University of South Florida. For more information, please contact digitalcommons@usf.edu. 


\section{GSA 2RTR}

4-7 Dovember
Implications for Groundwater Availability

Nick Soto-Kerans, Brian Hunt, Brian Smith
10. Barton Springs Edwards Aquifer
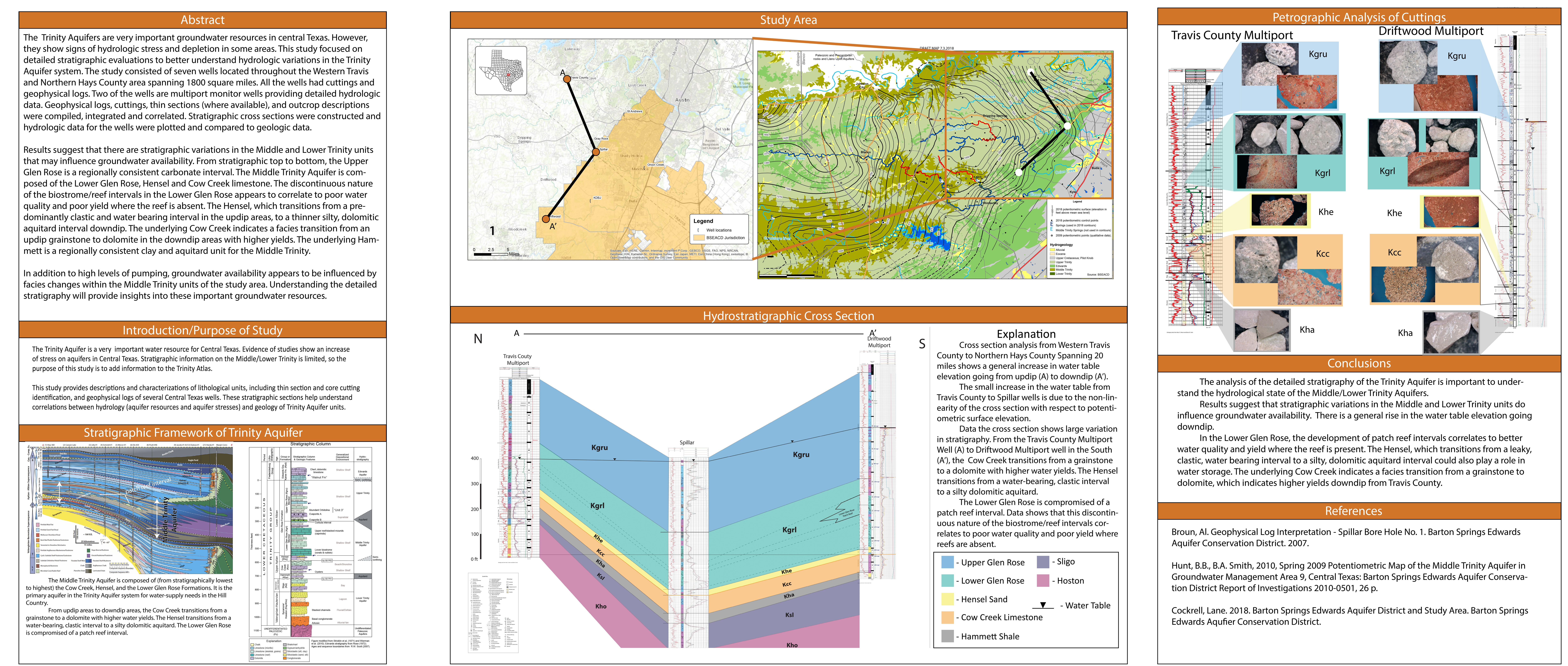